\title{
Adolescents' Perception of Religious Education According to Religion and Gender in Spain
}

\author{
María del Carmen Olmos-Gómez ${ }^{1, * \mathbb{C}}$, Rafael López-Cordero ${ }^{2, *}$ C , Sonia García-Segura ${ }^{3}$ (i) and \\ Francisca Ruiz-Garzón 1,* \\ 1 Department of Research Methods and Diagnosis in Education, Faculty of Education and Sport Science, \\ University of Granada, 52071 Melilla, Spain \\ 2 Department of Didactics of Social Science, Faculty of Education and Sport Science, University of Granada, \\ 52071 Melilla, Spain \\ 3 Department of Education, Faculty of Education Science, University of Córdoba, 14014 Córdoba, Spain; \\ sgsegura@uco.es \\ * Correspondence: mcolmos@ugr.es (M.d.C.O.-G.); raloco@ugr.es (R.L.-C.); fruizg@ugr.es (F.R.-G.)
}

Received: 27 September 2020; Accepted: 17 November 2020; Published: 19 November 2020

check for updates

\begin{abstract}
The aim of our study is to verify the influence of Religious Education on Spanish adolescents by applying a quantitative study based on descriptive and social research methods which reflect the religious and social plurality of Spain, with a total of 679 secondary education students. By means of the Delphi technique, an exploratory and semi-confirmatory factor analysis, and a confirmatory analysis using structural equations, the psychometric properties of the questionnaire designed are guaranteed. Using a multivariate analysis of variance, after the Levene test, multiple comparisons are made in order to assess the difference between religions and gender with respect to school Religious Education. Significant differences and large effect sizes are found. The results show first that experiences with regard to religion in school are more positive for the group of Christian women and that of Muslim men; second, that the knowledge of religion helps in the daily development of adolescents; third, that men from the two major religious groups and Jewish women demand more autonomy; and lastly, that students consider that the curricular development of religion in school should be reviewed, although it is confirmed that Religious Education is regarded as important for their life and future development.
\end{abstract}

Keywords: religious education; interreligious; Christian education; Islamic education; Jewish education; Hindu education

\section{Introduction}

When the issue of Intercultural Education is being addressed, the religious dimension in education must necessarily be considered (Keast 2007). The subject where sociocultural differences are most noticeable and where the challenges of diversity are most often put to the test may be Religious Education. This poses a number of challenges to curriculum designers and teachers in the classroom (Johannessen and Skeie 2019). It is insufficient to consider religious teaching solely as an academic matter. In fact, Religious Education may help us move towards a pluralistic approach to the teaching of religion (Navarrete et al. 2019).

In societies where there is a single dominant religious tradition and where that dominance is reflected in their institutional structure it is often difficult to convince policymakers and teachers of the relevance of plurality and secularity in the management of public schools. In such societies, prevailing religious traditions are considered unproblematic, as long as there are no tensions and divisions within those traditions (Bash 2019). People from every sect in Pakistan prefer to learn only about their own 
beliefs, despite or because of the fact that the division of Muslims into Sunni and Shia, and the further division of the former group into different sects, has led to widespread sectarian violence in the country. Ashraf (2019) found that most teachers participating in his study of religious literacy in Pakistan rejected the idea of teaching about other religions in schools since it would mean having to teach about something that they do not believe, or that cannot be applied to their religion, as it is a western concept. Moreover, they agreed that the Islamic way of life guarantees success. Therefore, it is considered unacceptable to learn about the beliefs of other religions or even other sects in Islam. In contrast, Tas (2019), in his study conducted in Turkey, examined the perceptions of primary school students regarding the lesson and teachers of religious culture and moral knowledge, and determined that these were mostly positive.

In countries such as Ireland, with a publicly funded school system characterized by a strong presence of Roman Catholic Church (Department of Education and Skills 2017), Religious Education has achieved a new status over the last two decades. This is largely due to the fact that it has become examinable, just as any other subject (Carmody 2019). The religious dimension was always Catholic in nature. With few exceptions, school personnel hardly questioned the role of religion in the life of the school (McCormack et al. 2019). In Israeli schools, there is a complex and changing situation: state-funded Jewish schools ('secular' and 'religious'); state-funded Arab (Muslim) schools; independently funded Christian (Arab) schools; independently funded 'ultra-orthodox' Jewish schools; etc. However, Jewish hegemony is taken for granted there. Despite its cultural-and religious-diversity, there is a clear lack of intercultural engagement in Israel (Bash 2019).

EU governments and religious organizations are joining efforts in the field of education in order to nurture spirituality while seeking to establish the limits of the influence of Religious Education on the general educational process at state-funded institutions. Europe is characterized by providing Religious Education within a multi-denominational education system. Therefore, it is necessary to develop Religious Education in each country based on its national culture and the traditions of its society (Dudin et al. 2019). Franken and Vermeer (2019) pay special attention to the cases of Belgium and the Netherlands when reflecting on the role of Religious Education in the school context, considering, on the one hand, the religious diversity and plurality among students and, on the other hand, the freedom of religion and education of religious schools. In this regard, Jackson and O'Grady (2019) describe the work of the Council of Europe on teaching about religions and non-religious worldviews, which is considered a major contributor to intercultural education, and introduce the concept of 'dialogical liberalism' in order to facilitate dialogue and discussion instead of imposing equality.

High school-age students seem to be influenced by the idea that modern science has refuted religious truth-claims (Walker 2019). Matemba and Addai-Mununkum (2019), in their study of schools in Malawi and Ghana, claim that Religious Education could even turn out to be counter-productive, resulting in the misrepresentation, rather than the promotion, of religions; particularly in those areas where a religion, such as Islam, has been hijacked by extremist groups with tragic consequences. This is the case of the recent terrorism activities perpetrated by ISIS in Europe, Al-Shabbab in in Kenya and Somalia, or Boko Haram in Nigeria. Experiences of religion-related dialogue in Sweden involving immigrant students from the Middle East with strong religious convictions reveal that historical and political conflicts in the Middle East influence, at least partially, students' willingness to have an open discussion (Vikdahl 2019). Meanwhile, da Gama et al. (2020) study how the impression of an ecumenical and multiculturalist bias in religious education in public educational institutions can be an effective means to deconstruct racist and prejudicial practices in relation to religions historically marginalized within school life. In search of this bias, Kimanen (2019) examines and juxtaposes discourses on religion and religious commitment of young Muslims and Protestants in the capital region of Finland. Her analysis shows that the Muslim background youth position consider themselves, being Muslims, to be in a privileged situation, while the majority of Protestant background youth tend to keep a certain distance from religion. 
Freathy and John (2019), within the project 'Principles and Big Ideas of Science Education', carried out at the University of Exeter (UK), advocate for an increased focus on multi-disciplinary, multi-methodological, inquiry-based, reflective learning, which questions the way in which our 'knowledge' of religions and worldviews is built. In this regard, four 'Big Ideas about the study of religions and worldviews' are postulated with the aim of highlighting the symbiotic relationship that exists between knowledge and knower, and of overcoming the false dichotomy that is often drawn between the object of study and the method of study (Freathy and John 2019). In the same vein, the research study on the integration of religious and non-religious worldviews in the school curriculum conducted in Norway and England by Braten and Everington (2019) discusses four issues: practical challenges; different understandings of the concept of worldviews; the inclusion of non-religious worldviews as a political issue and influences on the selection of worldviews.

Based on the previous analysis, the objectives of the present study were, first, to develop and validate an instrument to assess the impact of religion on schools in relation to the cultural background and gender of participants according to their culture and context; and second, to determine the possible relationship between the perception of religion in school and the variables gender and religion.

\section{Materials and Methods}

\subsection{Method}

For this research, which is descriptive in nature, a quantitative study was conducted. This quantitative strategy aimed to detect regularity from a positivist approach in order to identify the underlying causes of behavior combined with the social explanation of the relationship of the subject with their perception of reality. Thus, this study adopted a mixed-method approach, using analytical-empirical and social research methods (Howell 2008). This is a cross-sectional study based on a quasi-experimental methodology. Since the researchers cannot apply control techniques, they must be aware and take into account the possible consequences of the threat of differential selection in the planning of the study, as well as in its result and conclusions. A general approximation of reality is provided, but not in absolute values (Howell 2008).

\subsection{Participants}

The questionnaire was administered in secondary schools located in two different Spanish regions: Southeast of the Iberian Peninsula and Spanish North Africa. The selection of these regions was justified by the need to diversify the sample internally, and the aspects defined as the basis for comparison were urban vs. rural (immigrant population) and a strong tradition of limited religious plurality vs. multicultural religious diversity. Out of the total population, we chose seven schools located in the peninsula, in Southeastern Spain; and another seven schools located in Melilla, a Spanish North African city. The sample was comprised of students in their 2nd and 3rd year of secondary education, ranging from 14 to 16 years of age.

The religious education models followed by the schools under study are different, as are their levels of ethnic-religious diversity. They also have a different number of male and female students. This study involved 679 participants in total who were selected through non-probabilistic convenience sampling. Opinions were collected from 381 female (56.1\%) and 298 male students (43.9\%) in the 14- to 16-year-old age group (Mean $=14.94$ years). Regarding the variable 'religion', of the students who declared having a 'certain religion or worldview', $52 \%$ indicated that it was Catholicism, while $38 \%$ of them indicated it was Muslim. About 3\% stated that they were Jewish, and another 3\% affirmed that they practiced other religions. It is also worth noting that $1 \%$ of students chose another alternative and $3 \%$ did not respond. 


\subsection{Instrument}

Each participant received in person and on paper format the questionnaire developed for the present study. As an initial focus, in order to select the items to be included in the questionnaire, the questionnaire was administered to a group of students $(n=265)$ with similar characteristics to the sample used in the present study. After gathering the necessary information on the understanding of the questions and following the content validity process, the questionnaire was analyzed using the Delphi method (Escobar and Cuervo 2008). To do this, 11 experts were asked to evaluate the questionnaire and point out any element that could be regarded as unclear or poorly written in addition to suggesting recommendations on its relevance, appropriateness, coherence, and adequacy. All members of the group of experts held important positions in the religious and educational fields. The experts who participated as judges in the content validation process were professors at public and private universities, with PhDs in different areas of research (three male professors from a Catholic university and one female atheist professor), evolutionary psychology (a female Muslim professor and a female Jewish professor from a public university), social sciences (two priests who teach Catholic religion courses), and experimental sciences (a female Jewish professor and two male agnostic professors from a public university) which guaranteed their experience regarding this process. The final version of the adapted instrument was decided after three rounds of discussion. The percentage of agreement with respect to the relevance, appropriateness, coherence, and adequacy of the items ranged from $68 \%$ to $73 \%$ in the first round, from $74 \%$ to $81 \%$ in the second round, and from $82 \%$ to $91 \%$ in the third and last round.

Items with a percentage of agreement with respect to relevance, appropriateness, coherence, and adequacy lower than $70 \%$ were discarded or rewritten. Most elements remained unmodified, although four of them were completely removed and some others were regrouped. The final version of the questionnaire consisted of 38 questions divided into five dimensions.

The instrument (Appendix A) (Weisse 2009; European Commission 2011; Dietz et al. 2011) was divided into two parts. In the first part, participants were requested to provide personal details such as gender, age, and religion (How many years have you studied religion in school? Are you attending religion classes this school year?). The second part included questions about the frequency with which participants' opinions were expressed with respect to the item in question, and it was in turn divided into four sections): Experiences with religion in school; Autonomy of religion in school; Knowledge of religion contributes to life development, and; Teaching Models in Religious Education. A five-point scale was used that ranged from 1 to 5 , where 1 equals strongly agree and 5 equals strongly disagree. An exploratory and semi-confirmatory factor analysis was performed to examine the construct validity of the instruments. The value of the Kaiser-Meyer-Olkin (KMO) index was 0.972 and the result of Bartlett's test of sphericity was 0.000 , which made it possible to proceed to the semi-confirmatory factor analysis to validate the instrument. Finally, the analysis of the variance table revealed the existence of five factors that, when combined, explained $71.31 \%$ of the variance. We estimated the reliability of the scores obtained from the scale using Cronbach's Alpha, which was 0.918 (Elosua and Zumbo 2008).

Next, the multivariate regression coefficients based on structural equations were examined in order to confirm the factorial structure of the scale (González and Backhoff 2010). Regarding the application of the goodness-of-fit indices between the matrix derived from the data and the matrix reproduced by the model, it was observed that the two matrices were close, since the difference between them was not statistically significant, which indicates a good fit between the measurement model and the observed data.

Based on these parameters, and in order to ensure the convergence of the model, one more item was eliminated. A model was established with 90 degrees of freedom (df) and a $\chi 2$ of 123.93 . The $p$-value was below 0.05 , meaning that the difference between the compared covariance matrices (the derivative and the reproduced) was statistically significant (Bentler and Bonett 1980). The parsimonious normed fit index (PNFI) was 0.841, the comparative fit index (CFI) was 0.890, Tucker-Lewis Index (TLI) was 0.906 , the norm fit index (NFI) was 0.937 , and the root mean square error of approximation (RMSEA) 
was 0.048 (Bentler and Bonett 1980; Hu and Bentler 1999; Bentler 2007). All these results were excellent (Table 1).

Table 1. Adjustment index of the model of the Adolescent Perception of Religious Education (APREQ) questionnaire.

\begin{tabular}{cccccccccc}
\hline & \multicolumn{1}{c}{ Absolute Adjustment Index } & \multicolumn{3}{c}{ Increased Adjustment Index } \\
\hline Model & CMIN & P & LO 90 & HI 90 & RMSEA & PNFI & NFI & CFI & TLI \\
\hline $\begin{array}{c}\text { 4 Facts } \\
\text { 36 items }\end{array}$ & 822.7 & 0.000 & 0.043 & 0.071 & 0.048 & 0.841 & 0.937 & 0.890 & 0.906 \\
\hline
\end{tabular}

\subsection{Procedure}

\section{Data Collection Procedure}

The questionnaire was administered during the months of January and February 2020 with the permission of the families of the respondents and the approval of the directors of the participating secondary schools. The department of social responsibility and cooperation of the University of Granada also approved the study. The ethical principles of the Declaration of Helsinki were followed at all times. The students were given a paper-based questionnaire including a brief presentation, and then it was read as a group in order to allow for clarification questions. Each questionnaire took approximately $30 \mathrm{~min}$ to complete. Participants were given the guarantee of anonymity at all times and were informed that the data collected would be used only for research purposes.

\subsection{Data Analysis}

For the examination of the data, we performed a content analysis through the Delphi technique (Escobar and Cuervo 2008). Quantitative data were analyzed through an exploratory and semi-confirmatory factor analysis using the statistical program SPSS 24.0 (IBM SPSS Statistics 24.0, Chicago, IL, USA, 2016), (Martínez et al. 2019). Finally, through structural equation modeling, and by means of the statistical program LISREL v9.1, a confirmatory analysis was conducted (Scientific Software International, Princeton, NJ, USA, 2010).

Building on the psychometric reliability and construct validity of the questionnaire, the test for homogeneity of variance (Levene) was performed, which enabled the use of the parametric test (López-Roldán and Fachelli 2015). Besides, a multivariate analysis of variance (MANOVA) was used to study the relationships between the variables, perform multiple comparisons and assess the relationship between different religions and gender with respect to religious education in school.

\section{Results}

Table 2 shows the MANOVA and the effect size analyzed through the eta-squared values. The results indicate the existence of significant differences and large effect sizes between the different religions and gender with respect to religious education in school.

A multivariate test was carried out to identify the effects of the covariance, since it facilitates the statistical study of the influence of gender (with two categories: Male and female) and religion (with four categories (Christian, Muslim, Jewish and Hindu) in the coding of measurement at individual level. The results indicate significant differences and large effect sizes in relation to gender, religion, and the interaction between gender and religion. The sample size and proportion of variance explained (in ANOVA) (Andréu 2011; Cohen 1988) in relation to the factor 'Experiences with religion in school' with respect to the interactions gender and religion, yielded a result of $(\eta 2=0.17)$. It suggests that the proportion of differences can be attributed to the effect of Religious Education in school and to how it influences their life experiences, given that an effect above 0.14 is considered to be large (Badenes et al. 2018; Coe and Merino 2013; Lakens 2013). Likewise, the significant differences found, 
$p=0.000$, explain that this aforementioned factor is more positive for the group of Christian women and Muslim men. Significant differences are also shown in the factor 'Autonomy of religion in school', with students demanding more practical applications and autonomous development of religious knowledge than specified by the standard curriculum guide. This is supported by the results of $p=0.000$ and a sample effect of $(\eta 2=0.32)$. The men included in the two major religious groups and Jewish women are those who demand more autonomy. In relation to the factor 'Knowledge of religion contributes to life development', the results show that there are also significant differences in the interaction, and large effects of the sample $(\eta 2=0.21)$. The group of Jewish and Christian women are those who express that it helps in their development. Moreover, there are no differences between the Muslim groups according to sex, as both consider that such help is a consequence of their knowledge of religion. With regard to the fourth factor, where opinions about the 'Teaching models in Religion Education' are examined, the values obtained show the lowest mean, which indicates that students consider that the models should be reviewed. This idea is confirmed by the results of the second factor, autonomy, which is related to the curricular development of religion in school as well. The results point to significant differences in the interaction between gender and religion, with the groups of Christian men and Muslim women being those who showed a more critical view in relation to this factor.

Table 2. Sums of aggregated scales (ANOVA and effect size ( $\eta 2)$ ) for Religion in school by gender and religions.

\begin{tabular}{|c|c|c|c|c|c|c|c|c|}
\hline \multirow{2}{*}{\multicolumn{2}{|c|}{ Factors }} & \multirow[b]{2}{*}{$\mathbf{M}$} & \multirow[b]{2}{*}{ SD } & \multicolumn{2}{|c|}{ CI $(95 \%)$} & \multirow[b]{2}{*}{$\mathbf{F}$} & \multirow[b]{2}{*}{$p$} & \multirow[b]{2}{*}{$\eta^{2}$} \\
\hline & & & & $\begin{array}{l}\text { Lower } \\
\text { Limit }\end{array}$ & $\begin{array}{l}\text { Higher } \\
\text { Limit }\end{array}$ & & & \\
\hline \multirow{3}{*}{$\begin{array}{l}\text { Experiences with } \\
\text { religion in school }\end{array}$} & Gender & 4.36 & 0.791 & 3.83 & 4.66 & 0.483 & 0.003 & 0.26 \\
\hline & Religion & 3.96 & 0.853 & 3.53 & 4.12 & 1.251 & 0.001 & 0.19 \\
\hline & Gender $\times$ Religions & 4.02 & 0.866 & 3.85 & 4.22 & 2.244 & 0.000 & 0.17 \\
\hline \multirow{3}{*}{$\begin{array}{l}\text { Autonomy of religion in } \\
\text { school }\end{array}$} & Gender & 3.91 & 1.298 & 3.66 & 4.11 & 0.885 & 0.001 & 0.09 \\
\hline & Religion & 4.11 & 1.933 & 3.99 & 4.56 & 2.246 & 0.000 & 0.07 \\
\hline & Gender $\times$ Religions & 4.03 & 1.872 & 3.85 & 4.45 & 2.215 & 0.000 & 0.32 \\
\hline \multirow{3}{*}{$\begin{array}{l}\text { Knowledge of religion } \\
\text { contributes to life } \\
\text { development }\end{array}$} & Gender & 4.05 & 1.331 & 3.98 & 4.57 & 0.998 & 0.012 & 0.33 \\
\hline & Religion & 4.02 & 0.989 & 3.72 & 4.23 & 3.112 & 0.000 & 0.31 \\
\hline & Gender $\times$ Religions & 3.98 & 1.232 & 3.65 & 4.34 & 2.631 & 0.000 & 0.21 \\
\hline \multirow{3}{*}{$\begin{array}{l}\text { Teaching Models in } \\
\text { Religious Education }\end{array}$} & Gender & 3.23 & 0.875 & 2.86 & 3.51 & 0.989 & 0.001 & 0.23 \\
\hline & Religion & 3.19 & 0.816 & 3.03 & 3.24 & 2.842 & 0.000 & 0.21 \\
\hline & Gender $\times$ Religions & 3.04 & 0.979 & 2.83 & 3.31 & 1.487 & 0.000 & 0.16 \\
\hline
\end{tabular}

Note: The critical alpha level was adjusted for multiple testing to reduce the type I error $(\alpha)$. Thus, the $\alpha$-value was divided by the number of pair comparisons for each ANOVA.

\section{Discussion}

In the present study, we try to understand the role of Religion within the Spanish educational system through the perceptions and opinions of secondary school students regarding Religious Teaching throughout their educational process. The 'educational confrontation' with otherness should empower students with the capacity to be critical of their own religion and that of others (Vermeer 2010). This otherness can also be addressed with the knowledge of the typologies in the theoretical understanding of the field in terms of paradigms (da Cruz 2019). However, in order to teach it, we must first listen, attentively and patiently, to the same students we are trying to educate.

Experiences with religion in school are claimed by $86 \%$ of students questioned. Being able to develop knowledge about religion, promoting concepts such as respect and coexistence, discussing religious differences, understanding current affairs, getting to know yourself and the developing of values, among other perceptions, have been positively valued by all respondents. Christian women $(96 \%)$ and Muslim men (89\%) are those who have expressed the greatest satisfaction with respect to the experiences developed with religion in school. This enables us to affirm that religion in school is not 
only positive from the point of view of theoretical understanding, in terms of knowledge paradigms (da Cruz 2019), but also from the experiential perspective of the participating adolescents.

The autonomy of religion in school is one of the key issues raised by the participants, since students demand more practical applications and autonomous development of religious knowledge, with Muslim and Christian men as well as Jewish women advocating for greater autonomy. Religion should be dealt with in school under criteria developed in line with interdenominational dialogue, based on discussions and the exchange of ideas as innovative learning methodologies, with the development of forums separated by groups (large group and small groups) (Segura et al. 2020), to later interrelate positions. That could be a good meeting point for the development of the second factor of our study: Autonomy of religion in school.

$91 \%$ of respondents consider that the knowledge of religion contributes to life development. The process of justifying knowledge claims with evidence and reasons is often called 'argumentation' (Guilfoyle et al. 2020). The misuse or ignorance of the scientific and religious language is a drawback that hinders the development of interpersonal communication and, therefore, prevents the adoption of a possible pluralistic approach to the teaching of religions (Navarrete et al. 2019). Guilfoyle et al. (2020), in their research on the views of science and Religious Education teachers with respect to the nature of argumentation, referred to the increasing importance of the ability to coordinate knowledge and values in order to reach justified conclusions. Citizens face dilemmas where decisions are to be made in relation to science and religion. So, genetic cloning, nuclear power or climate change may not only potentially appeal to moral and religious values but also to scientific knowledge. In the present study, we observed that concepts such as 'worldview' were foreign to most students. We consider that Religious Education needs to pay attention to epistemic literacy if we aim to avoid epistemological misconceptions and enable students to develop their knowledge about the specific forms of knowledge manifested in religions (Pearce et al. 2019).

Teaching models regarding religious education should be reviewed in the development of the curriculum plan. Results suggest the idea that, although theoretical training is essential, the need for autonomy (second factor of our research) is equally important and can be fostered with greater religious dialogue and teaching innovations, which are critical in the teaching-learning process. That is why, in this cyber-communication world we live in, we should use tools that are adapted to the most popular communication systems among adolescents, such as social networks, in a cyber-intercultural and plural interreligious and international context, providing the necessary conditions for their correct use. However, face to face interactions should not be underestimated, as they may lead to the improvement of traditional models. Examples of these interactions would include the promotion of practical seminars conducted by experts through master classes, training experiences from a lecturing pedagogical approach, taught via practical applications in a school environment by a prestigious expert (Olmos-Gómez et al. 2019), and exchanges of experiences and knowledge of real situations.

In Finland, current and future teachers show different degrees of inter-religious sensitivity but the equal visibility of diverse traditions is primarily supported, without favoring strongly inclusive or exclusive practices (Niemi et al. 2020). Minorities are often perceived by the majority as deviant, especially when they stem from earlier religious schisms frequently regarded as apostates (Bash 2019). Sometimes, trying to integrate religious and non-religious worldviews, with the intention of protecting the beliefs of these minorities, creates tremendous difficulty for policy makers, teacher trainers, and schools (Braten and Everington 2019).

Another alleged ironist way of solving the conflict, with a westernized orientalism typical of the New Age, leads us to the current debate on Yoga and 'Mindfulness' in public schools. Candy (Brown 2019) proposes the implementation of religion in public schools through Yoga and Mindfulness. She describes the Buddhist origins and underlying nature of Mindfulness, presenting the idea that religion can just be subtracted from Yoga and Mindfulness and thus become secular (Brown 2019), which has initiated a controversial debate on the subject (Porterfield 2019; Neumann 2020; Mitchell 2020; VanTol 2020; Miller 2020). A different and less extreme view of 
secularity is taken, though, by many historians of religion, who consider that it emerges from the Christian and especially Protestant investment in individuality of the early modern era (Porterfield 2019).

It is worth highlighting that almost all the adolescents participating in this research study ascribed to a certain religion, and considered themselves believers, regardless of their religious practice.

\section{Conclusions}

In an attempt to reflect the religious and social plurality of Spain, this study has been carried out in three autonomous communities of the country: Southeast Spain and a Spanish city in North Africa. In total, 679 secondary education students, with an average age of 15 years, participated, which made it possible to statistically analyze the influence of gender (with two categories: Male and female) and religion (with four categories: Christian, Muslim, Jewish and Hindu), finding significant differences and large effect sizes.

According to our data, the study concludes that there are significant differences in the interaction between gender and religion, with the groups of Christian men and Muslim women being those who showed more critical view regarding to consider that the fact this helps is thanks to their knowledge of religion.

The importance of Religious Education which is reflected in the results can be attributed to the great effect of Religious Education in school and the way in which it influences the life experiences of students. Experiences regarding religion in school are more positive for the groups of Christian women and Muslim men. This is supported by literature on experiences such as that reported by Goren et al. (2019), who examined teachers' perceptions of Citizenship Education (CE) with a focus on the three main education sectors in Israel (secular-Jewish, religious-Jewish and Palestinian Arab) and found great differences in the interpretation of the term by teachers from each sector. For marginalized groups (Palestinian Arab), CE is regarded as a way of ensuring a sense of belonging to a global society. For social groups that are already well-resourced (secular Jews), CE is considered a way promoting the global future. Meanwhile, the Jewish religious minority in Israel see CE as a threat to national identity and religious values. The results of their study call into question the unifying potential of CE.

Knowledge of religion helps in the daily life of adolescents, with Jewish and Christian women being those who express this view more often. There are no differences in the Muslim group according to gender, as both consider that this help is thanks to their knowledge of religion. Men from the two major religious groups and Jewish women demand more autonomy.

Students consider that the curricular development of religion in school should be reviewed and demand more practical applications and autonomous development in religious knowledge than the specified in the standard curriculum guide. However, it has been found that they consider that Religious Education is important in their development, which is a key idea to highlight considering the age of respondents, since they have a short-term perception of life. This contrasts with the idea of the Council of Europe's 2008 'Recommendation', which encourages the study of 'non-religious convictions' in schools, in addition to religions, yet few European countries have incorporated non-religious worldviews within Religious Education (Braten and Everington 2019).

To conclude, it is important to emphasize the need to analyze the management of religious education in countries where the relationship between State and religion remains firmly rooted (as is the case of Spain), and the role of schools where confessional religion has a presence in schools (Garreta-Bochaca et al. 2019). However, for this analysis to be more accurate, it is necessary to contemplate not only the vision of parents, teachers (Olson et al. 2020), legislators (Malizia and Pieroni 2019; Markoviti 2019) and religious confessions (Silhol 2019); but also that of students, who can offer a perception of Religious Education based on their experience as insiders (Khalid et al. 2020). 
Author Contributions: M.d.C.O.-G., R.L.-C. and F.R.-G.: Conceptualization. M.d.C.O.-G.: Methodology and validation. S.G.-S. analyzed the data. M.d.C.O.-G. and R.L.-C.: Writing-review and editing. M.d.C.O.-G.: Supervision. All authors contributed to data interpretation of the analysis. M.d.C.O.-G., R.L.-C. and F.R.-G. wrote the paper with significant input from M.d.C.O.-G. All authors have read and agreed to the published version of the manuscript.

Funding: This research received no external funding.

Conflicts of Interest: The authors declare no conflict of interest.

\section{Appendix A. Adolescent Perception of Religious Education (APREQ) Questionnaire}

$$
\text { Sex: __ Female/__ Male }
$$

1. How many years have you studied religion in school?

2. Do you attend religion classes this school year?

\begin{tabular}{c}
$\frac{\text { Catholicism }}{\text { Muslim }}$ \\
$\frac{\text { Jewish }}{\text { Hindú }}$ \\
$\frac{\text { Agnostic }}{\text { Atheist }}$ \\
\hline Others \\
\hline
\end{tabular}

\begin{tabular}{|c|c|c|c|c|c|}
\hline $\begin{array}{l}\text { What Is Your Experience with Religion in } \\
\text { School? To What Extent Do You Agree That: }\end{array}$ & $\begin{array}{l}\text { Strongly } \\
\text { Agree }\end{array}$ & Agree & $\begin{array}{l}\text { Neither } \\
\text { Agree Nor } \\
\text { Disagree }\end{array}$ & Disagree & $\begin{array}{l}\text { Strongly } \\
\text { Disagree }\end{array}$ \\
\hline
\end{tabular}

At school I get knowledge about different religions.

At school I learn to respect everyone, regardless of their religion.

At school I have the opportunity to speak about

religious matters from different perspectives.

Topics dealing with religion in school are interesting.

I consider religions to be an important topic at school.

Learning about different religions helps us to live together.

Learning about religion in general helps me decide between good and bad.

Learning about religion in general helps me understand the current events.

Learning about religion in general helps me learn about myself.

Learning about religions leads to conflicts in the classroom. 


\begin{tabular}{|c|c|c|c|c|c|}
\hline $\begin{array}{l}\text { What Is Your Experience with Religion in } \\
\text { School? To What Extent Do You Agree That: }\end{array}$ & $\begin{array}{l}\text { Strongly } \\
\text { Agree }\end{array}$ & Agree & $\begin{array}{l}\text { Neither } \\
\text { Agree Nor } \\
\text { Disagree }\end{array}$ & Disagree & $\begin{array}{l}\text { Strongly } \\
\text { Disagree }\end{array}$ \\
\hline \multicolumn{6}{|l|}{$\begin{array}{l}\text { Religion can appear in school in many different } \\
\text { ways. Imagine that you are someone who has the } \\
\text { authority to decide about school affairs. To what } \\
\text { extent do you agree with the following positions? }\end{array}$} \\
\hline \multicolumn{6}{|l|}{$\begin{array}{l}\text { Religious dietary demands must be taken into } \\
\text { consideration at the school canteen. }\end{array}$} \\
\hline \multirow[t]{2}{*}{$\begin{array}{l}\text { Students should be able to wear } \\
\text { religious symbols in school. }\end{array}$} & & & & & \\
\hline & & & & & \\
\hline
\end{tabular}

It is acceptable for students not to attend class due to religious holidays.

Students should be excused from attending certain classes for religious reasons.

The school should provide spaces for students to pray.

Voluntary religious acts (e.g., prayers) could be part of the daily life of the school.

To what extent do you agree that learning about religions helps to:

Understand others and live with them peacefully.

Understand the history of my country and Europe.

Get a better understanding of current events.

Develop my own point of view.

Develop moral values.

Learn about my own religion.

What is your position regarding the different models of teaching religion in school?

Religion should be optional.

Students should study Religion separated into groups according to their religion.

There should be no place for religion in school.

Religion should be taught to all students together, regardless of students' religious or confessional differences.

The subject of Religion is not necessary.

All necessary topics are covered by other subjects in the school (e.g., Literature, History, etc.).

Religion should be taught partly together and partly in groups, according to the religion of students.

Get an objective knowledge of the religions of the world. 


\begin{tabular}{|c|c|c|c|c|c|}
\hline $\begin{array}{l}\text { What Is Your Experience with Religion in } \\
\text { School? To What Extent Do You Agree That: }\end{array}$ & $\begin{array}{l}\text { Strongly } \\
\text { Agree }\end{array}$ & Agree & $\begin{array}{c}\text { Neither } \\
\text { Agree Nor } \\
\text { Disagree }\end{array}$ & Disagree & $\begin{array}{l}\text { Strongly } \\
\text { Disagree }\end{array}$ \\
\hline \multicolumn{6}{|l|}{ Learn to understand what religions teach. } \\
\hline \multicolumn{6}{|l|}{ Be able to speak and converse on religious matters. } \\
\hline $\begin{array}{l}\text { Learn about the importance of religion to solve } \\
\text { problems in society. }\end{array}$ & & & & & \\
\hline
\end{tabular}

Note: Questionnaire based on the instrument used in the European project Religion in Education. A contribution to dialogue or a factor of conflict in transforming societies of European Countries (Weisse 2009; European Commission 2011; Dietz et al. 2011).

\section{References}

Andréu, Jaime. 2011. El análisis multinivel: Una revisión actualizada en el ámbito sociológico. Metodología de Encuestas 13: 161-76.

Ashraf, Muhammad Azeem. 2019. Exploring the Potential of Religious Literacy in Pakistani Education. Religions 10: 429. [CrossRef]

Badenes, Laura, Dolores Frías, and Amparo Bonilla. 2018. Un estudio exploratorio sobre el nivel de conocimiento sobre el tamaño del efecto y meta-análisis en psicólogos profesionales españoles. European Journal of Investigation in Health, Psychology and Education 7: 111-22. [CrossRef]

Bash, Leslie. 2019. Religion, schooling and the state: Negotiating and constructing the secular space. Revista Espanola De Educacion Comparada 33: 12-27. [CrossRef]

Bentler, Peter M. 2007. On tests and indices for evaluating structural models. Personality and Individual Differences 42: 825-29. [CrossRef]

Bentler, Peter, and Douglas Bonett. 1980. Significance tests and goodness of fit in the analysis of covariance structures. Psychological Bulletin 88: 588. [CrossRef]

Braten, Oddrun M. H., and Judith Everington. 2019. Issues in the integration of religious education and worldviews education in an intercultural context. Intercultural Education 30: 289-305. [CrossRef]

Brown, Candy Gunther. 2019. Debating Yoga and Mindfulness in Public Schools: Reforming Secular Education or Reestablishing Religion? Chapel Hill: UNC Press, pp. 1-441. [CrossRef]

Carmody, Brendan. 2019. Ecclesial to Public Space: Religion in Irish Secondary Schools. Religious Education 114: 551-64. [CrossRef]

Coe, Robert, and Cesar Merino. 2013. Efect Size: A guide for researchers and users. Revista de Psicología 21: 147-77.

Cohen, Jacob. 1988. Statistical Power Analysis for the Social Sciences. Hillsdale: Erlbaum Associates.

da Cruz, Eduardo Rodrigues. 2019. Revisiting two paradigms in the Study of Religion. Horizonte-Revista De Estudos De Teologia E Ciencias Da Religiao 17: 589-614. [CrossRef]

da Gama, Jamylly Kelly, Piedade Lino Videira, and Elivaldo Serrao Custodio. 2020. The relevance of the discipline Religious Education for the deconstruction of racist and prejudiced practices in daily school life. Estudos Teologicos 60: 98-112. [CrossRef]

Department of Education and Skills. 2017. Republic of Ireland. Available online: http://www.education.ie/en/ (accessed on 6 April 2017).

Dietz, Gunther, Francisco Javier Rosón-Lorente, and Francisca Ruiz-Garzón. 2011. Homogeneidad confesional en tiempos de pluralismo religioso. Revista CPU-e, Revista de Investigación Educativa 13: 1-42.

Dudin, Mihail Nikolaevich, Ekaterina Alexandrovna Pogrebinskaya, Elena Ivanovna Sukhova, and Alexey Nikolaevich Kirsanov. 2019. Modern religious education as the basis for the development of new confessional relations. European Journal of Science and Theology 15: 133-45.

Elosua, Paula, and Bruno Zumbo. 2008. Reliability coefficients for ordinal response scales. Psicothema 20: 896-901.

Escobar, Jazmine, and Angela Cuervo. 2008. Validez de contenido y juicio de expertos: Una aproximación a su utilización. Avances en Medición 6: 27-36. 
European Commission. 2011. Religion in Education. A contribution to Dialogue or a factor of Conflict in transforming societies of European Countries. Final Report Summary. REDCo. Available online: https://cordis.europa.eu/project/id/28384/reporting/es (accessed on 16 September 2020).

Franken, Leni, and Paul Vermeer. 2019. Deconfessionalising RE in pillarised education systems: A case study of Belgium and the Netherlands. British Journal of Religious Education 41: 272-85. [CrossRef]

Freathy, Rob, and Helen C. John. 2019. Religious Education, Big Ideas and the study of religion(s) and worldview(s). British Journal of Religious Education 41: 27-40. [CrossRef]

Garreta-Bochaca, Jordi, Monica Macia-Bordalba, and Nuria Llevot-Calvet. 2019. Religious education in state primary schools: The case of Catalonia (Spain). British Journal of Religious Education 41: 145-54. [CrossRef]

González, Manuel Jorge, and Eduardo Backhoff. 2010. Validación de un cuestionario de contexto para evaluar sistemas educativos con Modelos de Ecuaciones Estructurales. Revista Electrónica de Investigación y Evaluación Educativa 16: 1-17.

Goren, Heela, Claire Maxwell, and Miri Yemini. 2019. Israeli teachers make sense of global citizenship education in a divided society- religion, marginalisation and economic globalisation. Comparative Education 55: 243-63. [CrossRef]

Guilfoyle, Liam, Sibel Erduran, and Wonyong Park. 2020. An investigation into secondary teachers' views of argumentation in science and religious education. Journal of Beliefs \& Values-Studies in Religion E Education 16. [CrossRef]

Howell, David C. 2008. Fundamental Statistics for the Behavioral Sciences, 6th ed. Belmont: Thomson Wadsworth.

$\mathrm{Hu}$, Li-tze, and Peter M. Bentler. 1999. Cutoff criteria for fit indexes in covariance structure analysis: Conventional criteria versus new alternatives. Structural Equation Modeling: A Multidisciplinary Journal 6: 1-55. [CrossRef]

Jackson, Robert, and Kevin O'Grady. 2019. The religious and worldview dimension of intercultural education: The Council of Europe's contribution. Intercultural Education 30: 247-59. [CrossRef]

Johannessen, Oystein Lund, and Geir Skeie. 2019. The relationship between religious education and intercultural education. Intercultural Education 30: 260-74. [CrossRef]

Keast, John. 2007. Religious Diversity and Intercultural Education: A Reference Book for Schools. Strasbourg: Council of Europe Publishing, ISBN 978-92-871-6223-6.

Khalid, Fatima, Sultan Sikandar Mirza, Chai Bin-Feng, and Nighat Sae. 2020. Learning Engagements and the Role of Religion. Sage Open 10: 14. [CrossRef]

Kimanen, Anuleena. 2019. Finnish Muslim and Protestant Background Youth's Discourses on Religion and Religious Commitment. Religion E Education 46: 343-62. [CrossRef]

Lakens, Daniel. 2013. Calculating and reporting effect sizes to facilitate cumulative science: A practical primer for t-tests and ANOVAs. Frontiers in Psychology 4: 863. [CrossRef]

López-Roldán, Pedro, and Sandra Fachelli. 2015. Metodología de la Investigación Social Cuantitativa. Barcelona: Universitat Autònoma de Barcelona.

Malizia, Guglielmo, and Vittorio Pieroni. 2019. Empirical report of research on religious education in Italian Catholic schools (2017). International Studies in Catholic Education 11: 51-64. [CrossRef]

Markoviti, Margarita. 2019. In-between the Constitution and the European Court of Human Rights: Mobilizations around Religion and Education in Greece. Politics and Religion 12: S31-S54. [CrossRef]

Martínez, Asuncion, Maria del Carmen Olmos, Maria Tomé, and Eva Maria Olmedo. 2019. Analysis of Psychometric Properties and Validation of the Personal Learning Environments Questionnaire (PLE) and Social Integration of Unaccompanied Foreign Minors (MENA). Sustainability 11: 2903. [CrossRef]

Matemba, Yonah, and Richardson Addai-Mununkum. 2019. 'These religions are no good - they're nothing but idol worship': Mis/representation of religion in Religious Education at school in Malawi and Ghana. British Journal of Religious Education 41: 155-73. [CrossRef]

McCormack, Orla, Joanne O'Flaherty, Bryn O'Reilly, and Jennifer Liston. 2019. 'That's how it works here': The place of religion in publicly managed second-level schools in Ireland. British Educational Research Journal 45: 161-80. [CrossRef]

Miller, Joyce. 2020. Debating Yoga and Mindfulness in Public Schools: Reforming Secular Education or Reestablishing Religion? Journal of Contemporary Religion 35: 130-31. [CrossRef]

Mitchell, Matthew. 2020. Expanding the Debate: Responses to Candy Gunther Brown's Debating Yoga and Mindfulness in Public Schools: Reforming Secular Education or Reestablishing Religion? Religious Studies Review 46: 163. [CrossRef] 
Navarrete, Jessica, Angelica Vasquez, Efrain Montero, and Daniel Cantero. 2019. Significant learning in catholic religious education: The case of Temuco (Chile). British Journal of Religious Education 13. [CrossRef]

Neumann, David J. 2020. Debating Yoga and Mindfulness in Public Schools: Reforming Secular Education or Re-establishing Religion? Journal of American History 107: 256-57. [CrossRef]

Niemi, Pia Maria, Anuleena Kimanen, and Arto Kallioniemi. 2020. Including or excluding religion and worldviews in schools? Finnish teachers' and teacher students' perceptions. Journal of Beliefs $\mathcal{E}$ Values-Studies in Religion $\mathcal{E}$ Education 41: 114-28. [CrossRef]

Olmos-Gómez, Maria del Carmen, Ligia Isabel Estrada-Vidal, Francisca Ruiz-Garzón, Rafael López-Cordero, and Laila Mohamed-Mohand. 2019. Making future teachers more aware of issues related to sustainability: An Assessment of best practices. Sustainability 11: 7222. [CrossRef]

Olson, Laura R., Benjamin J. Bindewald, William D. McCorkle, and Suzanne N. Rosenblith. 2020. Public Schoolteachers' Attitudes about Religious Liberty in the Classroom. Religion E Education 47: 19-54. [CrossRef]

Pearce, Joanne, Alexis Stones, Michael. J. Reiss, and Tamjid Mujtaba. 2019. Science is purely about the truth so I don't think you could compare it to non-truth versus the truth. 'Students' perceptions of religion and science, and the relationship(s) between them: Religious education and the need for epistemic literacy. British Journal of Religious Education 16. [CrossRef]

Porterfield, Amanda. 2019. Debating Yoga and Mindfulness in Public Schools: Reforming Secular Education or Reestablishing Religion? Journal of Church and State 61: 736-38. [CrossRef]

Segura, Sonia G., Maria Jose Martinez Carmona, and Maria del Carmen Gil del Pino. 2020. Estudio descriptivo de la educación religiosa de estudiantes de secundaria de la provincia de Córdoba (España). Revista de humanidades 40: 179-98. [CrossRef]

Silhol, Guillaume. 2019. Regulating the time of religion: The teaching of the Catholic religion as an administrative device between the Italian public schools and the Catholic Church. Social Compass 66: 198-210. [CrossRef]

Tas, Halil. 2019. Metaphors of Elementary School Students Related to The Lesson and Teachers of Religious Culture and Moral Knowledge. Cumhuriyet Ilahiyat Dergisi-Cumhuriyet Theology Journal 23: 29-51. [CrossRef]

VanTol, Kathleen. 2020. Debating Yoga and Mindfulness in Public Schools: Reforming Secular Education or Reestablishing Religion? International Journal of Christianity $\mathcal{E}$ Education 24: 220-21. [CrossRef]

Vermeer, Paul. 2010. Religious Education and Socialization. Religious Education 105: 103-16. [CrossRef]

Vikdahl, Linda. 2019. A lot is at stake: On the possibilities for religion-related dialog in a school in Sweden. Religion E Education 46: 81-100. [CrossRef]

Walker, Timothy. 2019. Science and religion in the classroom: A philosophical approach. International Studies in Catholic Education 11: 96-109. [CrossRef]

Weisse, Wolfram. 2009. Religión en Educación: Contribución al Diálogo. Sugerencias del Proyecto de Investigación REDCO para la Política. Comisión Europea. Available online: https://www.awr.uni-hamburg.de/websitecontent/pdfsforschung/interreligioeser-dialog-zwid.pdf (accessed on 10 September 2020).

Publisher's Note: MDPI stays neutral with regard to jurisdictional claims in published maps and institutional affiliations.

(C) 2020 by the authors. Licensee MDPI, Basel, Switzerland. This article is an open access article distributed under the terms and conditions of the Creative Commons Attribution (CC BY) license (http://creativecommons.org/licenses/by/4.0/). 